\title{
TIETO VALINNANVAPAUDEN EDELLYTYKSENÄ
}

\section{Miten Mikä Kunto? -viestintäkampanjalla onnistuttiin lisäämään tietoa nuorten kuntoutuspalveluista?}

\section{Johdanto}

Asiakkaan valinnanvapauden lisääminen on osa suomalaisen sosiaali- ja terveyspalvelujärjestelmän uudistamista. Vuodesta 2014 alkaen asiakkaan on ollut mahdollista valita terveysasemansa ja erikoissairaanhoidon yksikkönsä kaikista julkisista terveysasemista ja sairaaloista (Terveydenhuoltolaki 2010/1326). Jatkossa valinnanvapaus todennäköisesti laajenee myös kolmannen sektorin palveluihin (Valtioneuvoston kanslia 2015). Suomalaisen valinnanvapausmallin valmistelun tavoitteena on hyvinvointi- ja terveyserojen kaventaminen ja palvelujen saatavuuden parantaminen. Valintaoikeudella pyritään tukemaan asiakkaiden itsemääräämisoikeutta ja heidän vastuunottoaan omasta terveydestään ja hyvinvoinnistaan. (Sosiaali- ja terveysministeriö Et valtiovarainministeriö 2016.) Valinnanvapauden lisäämisen voidaan ajatella sekä vapauttavan että vastuuttavan asiakasta. Huolta on herättänyt se, saavatko kaikki palveluihin oikeutetut riittävästi tietoa palvelujen laadusta ja oikeudestaan niihin kyetäkseen valintojen tekemiseen (esim. SOSTE 2016).

Kuntoutusverkoston asiantuntijoiden mukaan (SOSTE 2016) valinnanvapaus kuntoutuspalveluissa monipuolistanee palveluvaihtoehtoja sekä lisännee kuntoutujien hyvinvointia: kuntoutuja saa yksilöllisten tarpeidensa mukaista tukea ja palveluita. Toisaalta valinnanvapaus saattaa kasvattaa hyvinvointieroja. Heikommassa asemassa olevat eivät välttämättä pääse nykyistä helpommin kuntoutuspalveluihin. Puutteellinen palveluohjaus, palvelupolkujen katkeaminen ja vähäinen yhteistyö sidosryhmien välillä koetaan valinnanvapauteen liittyvinä uhkina. (SOSTE 2016.) Valinnanvapausmallin valmistelussa pyritään ottamaan huomioon, että osalla asiakkaista on rajalliset mahdollisuudet käyttää valintaoikeuttaan. Näille asiakasryhmille on tarkoitus tarjota tukea päätöksentekoon. (Sosiaali- ja terveysministeriö \&t valtiovarainministeriö 2016.)

Kela järjestää ammatillisia ja mielenterveyskuntoutuspalveluita niille nuorille, joiden opiskelu- tai työkyky on heikentynyt sairauden tai vamman vuoksi. Vuonna 2015 Kelan kuntoutuksen piirissä oli 14395 iältään 16-24-vuotiasta nuorta (Kelan tilastollinen vuosikirja 2015, 235). Nuoret tuntevat kuntoutusmahdollisuudet huonosti, vaikka heillä olisi työllistymistä tai kouluttautumista vaikeuttavia toimintakyvyn rajoitteita (esim. Korkeamäki 2015). Ratkaisuna kuntoutuspalveluiden heikkoon tunnettuuteen Kela toteutti vuosien 2015 ja 2016 aikana Mikä Kunto? -viestintäkampanjan nuorten kuntoutuspalveluista. Kampanjan tavoitteena oli lisätä nuorten ja nuorten kanssa työskentelevien tietoisuutta Kelan järjestämistä kuntoutuspalveluista. 
Tässä tutkimuksessa tarkastellaan, miten Mikä Kunto? -viestintäkampanja tavoitti kohderyhmänsä ja herättikö kampanja nuorten kiinnostusta kuntoutusta kohtaan eli miten kampanja on näkynyt nuorten yhteydenotoissa ammattilaisiin. Tulosten avulla pohditaan, mitä viestintäkampanjan onnistuminen kertoo valinnanvapauden toteutumisen edellytyksistä nuorten kuntoutuspalveluissa. Kuntoutuksen todellisia hakijamääriä ei sisällytetty tutkimukseen, koska kampanjan aikana toteutuneet lakimuutokset ja muutokset palveluissa vaikeuttavat näistä luvuista tehtäviä johtopäätöksiä. Lisäksi kampanjassa markkinoitiin sosiaaliturvaetuutta, jota saadakseen asiakkaan on täytettävä tietyt myöntökriteerit, eli nuorten herännyt kiinnostus kuntoutusta kohtaan ei siten välttämättä suoraan heijastu hakijamääriin. Tutkimuksen informantteina ovat kampanjan kohderyhminä olleet 16-30-vuotiaat nuoret, nuorten kuntoutuksen palveluntuottajat, etsivät nuorisotyöntekijät ja kuntoutuksen palvelunumerossa työskentelevät Kelan työntekijät. Tutkimuksen aineisto kerättiin touko-kesäkuussa 2016 puhelinhaastatteluna ja internetkyselyin. Lisäksi tutkimuksessa tarkastellaan Mikä Kunto? -kampanjasivuston kävijämääriä.

\section{Tieto ja valinnanvapauden edellytykset}

Valinnanvapausmallin tarkoituksena on kehittää sosiaali- ja terveyspalveluita, kun asiakkaiden valinnat ohjaavat julkisia resursseja kohti laadukkaita palveluja (esim. Jonsson \&t Virtanen 2013).

Taustaoletuksena on, että asiakkaat haluavat laadukasta hoitoa mahdollisimman vähäisillä kustannuksilla. Asiakkaat vertailevat palvelujen hintoja ja tietoja hoidon laadusta ja valitsevat palveluntuottajan näiden tietojen perusteella. (Victoor ym. 2012.) Valinnanvapauden toteutuminen edellyttää, että asiakkaalla on tieto valintaoikeudestaan ja halu käyttää oikeutta, hänellä on vaihtoehtoja, joista valita, ja hänen saatavillaan on ymmärrettävää vertailutietoa vaihtoehdoista. Lisäksi hänen tulee tarvittaessa saada tukea valinnan tekemiseen. (Junnila ym. 2016.)
Valinnanvapaus perustuu ajatukseen toimijasta, joka kykenee vertailemaan vaihtoehtoja ja saatavilla olevan tiedon perusteella valitsemaan palvelunsa tuottajan. Ajatellaan, että mielekkäiden valintojen tekeminen on mahdollista, kun valinnan tueksi on tarjolla ymmärrettävää tietoa vaihtoehdoista (esim. Jonsson \&t Virtanen 2013). Suunnitellun toiminnan teoria ennustaa ihmisten käyttäytymistä ja valintoja tilanteissa, joissa he käyttävät saatavillaan olevaa tietoa valintojensa tekemiseen ja kykenevät arvioimaan valintojensa seurauksia (Ajzen 2005, 117). Teorian mukaan (Ajzen 2005, 117-127) aikomus valita ennustaa todellista valintaa. Aikomuksen taustalla ovat myönteiset asenteet käyttäytymistä ja sen seurauksia kohtaan sekä sosiaalisen ympäristön, kuten perheen ja ystävien, myönteinen suhtautuminen valintaa kohtaan ja henkilön halu toimia läheisten odotusten mukaan. Näiden lisäksi valintaa ennustaa henkilön uskomus siitä, että hän kykenee valitsemaan tai että valinnalle ei ole merkittäviä esteitä. Näiden kolmen osatekijän tärkeys riippuu henkilöstä ja siitä, millaisesta käyttäytymisen muutoksesta tai valinnasta on kyse. Teorian mukaan tieto vaikuttaa käyttäytymiseen näiden kolmen tekijän kautta henkilön muiden taustatekijöiden, kuten iän, sosioekonomisen aseman ja aiempien kokemusten, tapaan (Ajzen 2005, 134-136). Aina pelkän valintaa tukevan aikomuksen luominen ei johda todelliseen valintaan tai käyttäytymisen muutokseen (esim. Ajzen 2005, 139).

Terveyteen liittyvä päätöksenteko eroaa kuitenkin muista päätöksentekotilanteista, joita kuluttajat kohtaavat. Viitaten Kahnemanin ja Tverskyn (1979) inhimillistä päätöksentekoa avaavaan teoriaan Fotaki kumppaneineen (2008) toteaa, että terveyteen liittyviä valintoja tehdessään kuluttajan on arvioitava monimutkaista tietoa usein epävarmassa ja stressaavassa elämäntilanteessa. Tiedetään, että motivaatio ja kyky käsitellä tietoa ennustavat sitä, käsitteleekö henkilö saatavilla olevaa tietoa perusteellisesti vai vaikuttavatko tiedonkäsittelyyn pinnallisemmat tekijät, kuten se, kuka tiedon antaa (esim. Petty \& Cacioppo 1986). Asiakkaat eivät usein käytä 
päätöksenteossaan kaikkea saatavilla olevaa tietoa: tietoa saattaa olla liikaa tai se on ristiriitaista (Damman ym. 2009). On myös havaittu, että esimerkiksi paremmassa sosioekonomisessa asemassa olevat asiakkaat hyödyntävät todennäköisemmin saatavilla olevaa tietoa palveluntuottajista (Fotaki ym. 2008).

\section{Viestintäkampanja ratkaisuna kuntoutus- etuuden huonoon tunnettuuteen}

Terveys 2000 -tutkimuksessa jo nuorilla aikuisilla havaittiin väestöryhmittäisiä eroja terveydessä ja toimintakyvyssä (Martelin ym. 2005, 145). Yleisimpiä toimintakyvyn rajoitteita nuorilla ovat psyykkiset ja sosiaaliset rajoitteet (Shemeikka ym. 2015), jotka tyypillisesti kasautuvat vain perusasteen tutkinnon suorittaneille (Martelin ym. 2005, 145; Shemeikka ym. 2015). Toimintakyvyn rajoitteet voivat nuorten ikäryhmässä johtaa pysyviin kehityskulkuihin, kun esimerkiksi opiskeluelämän ongelmat heikentävät myöhempiä työllistymismahdollisuuksia (Shemeikka ym. 2015). Nuorisotyöttömyyden ja syrjäytymisen taustalla on usein mielenterveysongelmia tai oppimisvaikeuksia (Gustavsson-Lilius ym. 2015).

Tuusan ja kumppaneiden $(2014,21) \mathrm{mu}-$ kaan nuorista 17 prosenttia arvioi tarvitsevansa henkistä jaksamista tukevaa kuntoutusta ja 3-5 prosenttia fyysistä jaksamista, opintoihin valmiuksia antavaa tai ammatillisia valmiuksia edistävää kuntoutusta. Harva nuori kuitenkaan tuntee kuntoutusmahdollisuudet (Korkeamäki 2015; Tuusa ym. 2014, 21). Korkeamäen (2015) tutkimuksessa kuntoutusmahdollisuuksia tunsivat vain ne nuoret, joille ammattilaiset olivat esitelleet niitä. Myös Kelan asiakastyössä on havaittu, etteivät nuoret hakeudu tai heitä ei ohjata oikea-aikaisesti Kelan kuntoutuspalveluiden piiriin. Esimerkiksi masennus- ja ahdistusoireisiin kuntoutusta tarjoavia nuorten mielenterveyskursseja on jäänyt toteutumatta osallistujamäärien vähäisyyden vuoksi.

Nuorten kohdalla kuntoutusetuus on siis todennäköisesti alikäytetty sosiaaliturvaetuus. Yhtenä syynä sosiaaliturvaetuuksien alikäyt- töön on esitetty informaatiovajetta: henkilö ei tiedä oikeudestaan etuuteen tai etuuden hakuprosessi kuvitellaan todellista monimutkaisemmaksi (esim. Currie 2006, 87). Korkeamäen (2015) mukaan nuoret kokevat etuuksien hakemisen työlääksi ja kuntoutusjärjestelmän vaikeaselkoiseksi.

\section{Mikä Kunto? -viestintäkampanja}

Kelan toteuttaman Mikä Kunto? -viestintäkampanjan keskeisenä tavoitteena oli lisätä nuorten ja nuorten kanssa työskentelevien tietoisuutta Kelan järjestämistä kuntoutuspalveluista. Viestintäkampanja oli Kelalle uudenlainen tapa viestiä sosiaaliturvaetuudesta. Ennen kampanjaa nuorille on tarjottu tietoa kuntoutuspalveluista pääosin esitteillä ja Kelan verkkosivustolla (kela.fi). Mainonta kohdistettiin 16-30-vuotiaille nuorille ja niille tahoille, jotka todennäköisimmin ohjaavat nuoria kuntoutuspalveluihin. Kampanjassa markkinoitiin ammatillista kuntoutusta, kuntoutuspsykoterapiaa ja mielenterveyskursseja.

Osana viestintäkampanjaa perustettiin Mikä Kunto? -verkkosivusto (nuortenkuntoutus.kela.fi). Kampanjan ilmettä ja iskulausetta (Mikä Kunto?) oli valitsemassa viisi nuorta. Kampanjasivustolla kerrottiin, millaisessa elämäntilanteessa ja miten Kelan kuntoutuspalveluihin voi hakeutua ja ohjattiin nuoria soittamaan Kelan kuntoutuksen palvelunumeroon, jos he kaipasivat lisätietoja kuntoutuksesta. Sivustolla oli tietoa siitä, missä kuntoutuspalveluita toteutetaan, ja palveluntuottajien yhteystiedot lisäkysymyksiä varten. Kuntoutuspalveluiden tuottajia myös osallistettiin kampanjaan: he saivat tuottaa sisältöä kampanjasivustolle jakamalla kuntoutusaiheisia kuvia Instagram-kuvanjakopalvelussa (\# mikakunto), ja heille järjestettiin viestintäkoulutuksia muun muassa sosiaalisen median käytöstä palveluiden markkinoinnissa. Lisäksi sivustolla kerrottiin, miten etsivä nuorisotyö voi auttaa nuorta. Sivuston kautta nuori voi etsiä oman kuntansa etsivien nuorisotyöntekijöiden yhteystiedot. Suomenkielinen kampanjasivusto avattiin toukokuussa 2015 ja ruotsinkielinen tammikuussa 2016. Tässä tutkimuksessa tarkastellaan suomenkielistä kampanjaa. 
Mikä Kunto? -kampanjan toteuttamisessa otettiin huomioon käyttäytymisen muutosta ennustavia tekijöitä (esim. Ajzen 2005, 117127). Kampanjassa luotiin mielikuva siitä, että kuntoutuksella voi olla myönteisiä seurauksia nuoren elämässä ja että nuorelle merkityksellisillä henkilöillä on myönteisiä kokemuksia kuntoutuksesta. Kampanjassa kerrottiin, että kuntoutuksen avulla nuori voi löytää uuden suunnan elämäänsä, kun elämä tuntuu olevan solmussa. Osana kampanjaa järjestettiin kirjoituskilpailu, jossa kuntoutuksessa olleita nuoria pyydettiin kertomaan kokemuksiaan kuntoutuksesta. Lisäksi nuorten suosima videobloggaaja Eetu Pesonen kertoi kuntoutuksen hyödyistä Youtube-videopalveluun lisätyillä videoilla. Konkreettiset ohjeet siihen, miten kuntoutukseen hakeudutaan, ja muun muassa Kelan puhelinpalvelun yhteystiedot lisäkysymyksien varalle poistivat kuntoutukseen hakeutumisen tiedollisia esteitä ja tarjosivat väylän tuen hakemiseen.

Kampanjaa mainostettiin kolmena ajankohtana: toukokuussa ja elokuussa 2015 sekä tammikuussa 2016. Kahtena ensimmäisenä ajankohtana kampanjaa markkinoitiin hakusanamainonnalla, bannereilla eli internetin mainospaikoilla ja Youtubessa ja tammikuussa 2016 videomainoksella Yleisradion TV1-kanavalla, Finnkinon elokuvateattereissa ja Youtubessa. Viimeisessä kampanjalähdössä mainonnan kohderyhmänä olivat nuorten lisäksi nuorten vanhemmat ja nuorten kanssa työskentelevät. Kaikki kampanjalähdöt kestivät noin kaksi viikkoa. Lisäksi kampanjaa mainostettiin aiheeseen liittyvissä tapahtumissa kuten Youtube-yhteisön livetapahtumassa Tubeconissa Helsingissä elokuussa 2015 ja Mielenterveysmessuilla Helsingissä marraskuussa 2015.

Kampanjan ensimmäisen mainoslähdön jälkeen kampanjan toteuttanut viestintätoimisto toteutti alkumittauksen (OMD 2015), jolla se arvioi nuorten suhtautumista kampanjamainontaan ja sitä, miten kampanja on tavoittanut nuoret. Seitsemän prosenttia tutkituista 15-29-vuotiaista nuorista $(\mathrm{n}=312)$ muisti kampanjan ainoastaan nimen perusteella ja 26 prosenttia muisti nähneensä ainakin jota- kin kampanjamainontaa mainoksien näyttämisen jälkeen. Tutkimus toteutettiin internetkyselynä kuluttajapaneelille eli sen otos oli näyte kampanjan kohderyhmään kuuluneista 16-30-vuotiaista nuorista. Nuorten matalankynnyksen palvelupisteitä, Ohjaamoita, koskevassa tutkimuksessa (Paavonen \& Salminen 2016) kaksi prosenttia nuorista kertoi huomanneensa kampanjan. Tutkimukseen osallistui sata Ohjaamon asiakasta.

Vastaavanlaista markkinointia on Suomessa toteutettu vähän. Sosiaali- ja terveysministeriön vuosina 2007-2008 toteuttaman perhevapaakampanjan tavoitteena oli lisätä tietoisuutta perhevapaauudistuksesta ja tukea isyyslomien käyttöä. Kampanjassa annettiin televisio- ja radiomainonnan lisäksi suoraa puhelinneuvontaa isyysvapaan potentiaalisille käyttäjille. Heti kampanjamainonnan jälkeen tehdyn mittauksen mukaan 99 prosenttia tuoreista isistä oli tavoitettu kampanjaviesteillä ja kampanja sai puolet vastaajista harkitsemaan isyysvapaan pitämistä. (Eloranta 2008.) Kansainvälistä tutkimustietoa sosiaalietuuksien markkinointikampanjoista on runsaasti. Esimerkiksi Yhdysvalloissa vähävaraisille perheille annettu henkilökohtainen neuvonta koulutustuesta kasvatti tuen hakijamääriä, ja tukea myönnettiin useammalle (Bettinger ym. 2012).

\section{Tutkimuskysymykset}

Tässä tutkimuksessa tarkastellaan, miten Mikä Kunto? -kampanja on tavoittanut kohderyhmänsä ja millaisia vaikutuksia kampanjalla on ollut. Osana jälkimmäistä kysymystä tutkimuksessa arvioidaan, herättikö kampanja nuorissa kiinnostuksen kuntoutusta kohtaan eli mahdollisesti aikomuksen hakeutua kuntoutukseen. Tätä mitataan nuorten yhteydenottojen määränä ammattilaisiin. Tulosten avulla pohditaan, riittääkö tiedon lisääminen kuntoutuksesta hyötyvien nuorten tavoittamiseksi ja ohjautumiseksi Kelan järjestämien kuntoutuspalveluiden piiriin sekä millaisia edellytyksiä valinnanvapauden toteutumiselle on nuorten kuntoutuspalveluissa. Tutkimuskysymyksinä ovat: 
1) Miten Mikä kunto? -kampanja on tavoittanut kohderyhmänsä?

2) Miten tiedon lisääminen nuorten kuntoutuspalveluista on näkynyt nuorten yhteydenotoissa ammattilaisiin?

\section{Tutkimuksen aineisto}

Artikkeli perustuu touko-kesäkuussa 2016 kerättyyn Mikä Kunto? -nuorten kuntoutuspalveluiden viestintäkampanjan onnistuminen -tutkimuksen aineistoon. Aineisto on moninäkökulmainen ja -menetelmällinen: aineistotriangulaation avulla kampanjan onnistumista on mahdollista arvioida kampanjan kaikkien kohderyhmien näkökulmasta (Eskola \& $\mathrm{Suo-}$ ranta 2000, 68).

Palveluntuottajien, etsivien nuorisotyöntekijöiden ja Kelan palveluneuvojien internetkyselyt toteutettiin Digium-verkkokyselytyökalulla 16. toukokuuta ja 3. kesäkuuta välisenä aikana ja nuorten puhelinhaastattelu toukokuussa 2016. Kyselyaineistot analysoitiin SPSS-tilastoanalyysiohjelmalla. Tulokset ovat aineistoa kuvailevia. Kaikkien vastaajaryhmien asuinpaikka tai työskentelyalue luokiteltiin Euroopan tilastovirasto Eurostatin NUTS 2 -alueluokituksen mukaisesti neljään luokkaan (esim. Tilastokeskus 2015, 7). Kelan palveluneuvojilta työskentelyaluetta ei kysytty, koska Kelan palvelunumerot palvelevat valtakunnallisesti. Kyselyaineistojen avovastauksien analyysimenetelmänä käytettiin aineistolähtöistä sisällönanalyysiä (Eskola \&t Suoranta 2000, 186). Viestintäkampanjan arviointia täydennetään kampanjasivuston kävijätietoja tarkastelemalla. Kampanjasivuston kävijätiedot poimittiin Google Analytics -verkkosivustojen kävijäseurantapalvelusta kesäkuussa 2016.

\section{Nuoret}

Nuorten aineiston keräsi Kelan toimeksiannosta Taloustutkimus Oy puhelinhaastatteluna. Iältään 16-30-vuotiaiden nuorten otos muodostettiin satunnaisotannalla Väestörekisterikeskuksen rekisteristä, ja se kiintiöitiin vastaajien iän, sukupuolen ja asuinpaikan mukaan. Puhelinhaastatteluun osallistui 584 nuorta. Otos edustaa tilastollisesti 16-30-vuo-
Taulukko 1. Vastanneiden nuorten taustatiedot, \% $(n=584)$.

\begin{tabular}{|lr|}
\hline Sukupuoli & \\
\hline Nainen & 48 \\
Mies & 52 \\
\hline Ikäryhmä & \\
\hline $16-20$ vuotta & \\
$21-25$ vuotta & 30 \\
26-30 vuotta & 35 \\
& 34 \\
\hline Koulutustaso & \\
\hline Perusaste & \\
Ammatillinen koulutus & 20 \\
Ylioppilas/lukio & 25 \\
Opistotaso & 28 \\
Ammattikorkeakoulu & 2 \\
Yliopisto/ korkeakoulu & 11 \\
Ei halua vastata & 13 \\
\hline Suuralue & 1 \\
\hline Helsinki-Uusimaa & \\
Etelä-Suomi & 31 \\
Länsi-Suomi & 17 \\
Pohjois- ja Itä-Suomi & 29 \\
\hline
\end{tabular}

tiaiden ikäryhmää Suomessa. Taustatietoina nuorilta kysyttiin sukupuolta, ikää, koulutusta ja asuinpaikkakuntaa. Tutkimukseen osallistuneiden nuorten taustatiedot esitetään taulukossa 1.

\section{Kuntoutuksen palveluntuottajat}

Internetkysely lähetettiin niille Kelan palveluntuottajarekisterissä oleville palveluntuottajille, jotka tuottavat kampanjassa mainostettuja nuorten kuntoutuspalveluita eli ammatillista ja mielenterveyskuntoutusta. Tutkimuksesta rajattiin pois ammatillisen koulutuksen ja kuntoutuspsykoterapian palveluntuottajat, koska niiden tuottajamäärät ovat useita tuhansia ja nuorten kuntoutujien määrä yhtä palveluntuottajaa kohden on tyypillisesti vähäinen. Sähköpostiosoitteet kerättiin palveluntuottajien verkkosivuilta. Kysely lähetettiin useimmiten organisaatioiden toimipaikkavastaaville tai palvelupäälliköille. Yhteyshenkilöitä kehotettiin vastaamaan kyselyyn yhdessä organisaationsa henkilökunnan kanssa tai sellaisen työntekijänsä kanssa, joka parhaiten 
tuntee organisaation tuottamia Kelan järjestämiä nuorten kuntoutuspalveluita. Kysely lähetettiin 65 henkilölle ja siihen vastasi 19 henkilöä (vastausprosentti: 29).

Kuntoutuksen palveluntuottajien taustatietoina kysyttiin, millä alueella heidän toimipisteensä sijaitsee, millaisia kuntoutuspalveluita he tuottavat ja kuinka suuri osuus heidän tuottamistaan kuntoutuspalveluista on suunnattu nuorille. Suurin osa vastanneista palveluntuottajista ilmoitti toimipisteensä sijoittuvan Pohjois- ja Itä-Suomen alueelle (taulukko 2). Jakauma noudattaa palveluntuottajien perusjoukon jakaumaa. Yli puolet kyselyyn vastanneista palveluntuottajista tuotti merkittävän osan (25-50 \%) palveluistaan nuorille. Hieman yli puolet vastaajista kertoi olleensa mukana kampanjassa. Palveluntuottajat olivat muun muassa osallistuneet heille järjestettyyn

Taulukko 2. Vastanneiden palveluntuottajien taustatiedot, \%.

\begin{tabular}{|c|c|}
\hline \multicolumn{2}{|l|}{ Suuralue $(n=19)$} \\
\hline Länsi-Suomi & 16 \\
\hline Helsinki-Uusimaa & 5 \\
\hline Etelä-Suomi & 16 \\
\hline Pohjois- ja Itä-Suomi & 63 \\
\hline \multicolumn{2}{|l|}{ Kuntoutuspalvelu, jota tuottaa $(n=19)^{1}$} \\
\hline Ammatillinen kuntoutusselvitys & 37 \\
\hline Ammatillinen kurssi & 32 \\
\hline Koulutuskokeilu & 0 \\
\hline Mielenterveyskurssi & 16 \\
\hline Mielenterveyskuntoutujien työhönvalmennus & 68 \\
\hline Työhönvalmennus & 53 \\
\hline Työkokeilu & 58 \\
\hline Jokin muu & 21 \\
\hline \multicolumn{2}{|l|}{$\begin{array}{l}\text { Nuorten kuntoutuspalveluiden osuus tuotetuista } \\
\text { palveluista }(n=18)\end{array}$} \\
\hline Alle $25 \%$ & 39 \\
\hline $25-50 \%$ & 56 \\
\hline $51-75 \%$ & 0 \\
\hline Yli $75 \%$ & 6 \\
\hline Järjestämme vain nuorten kuntoutuspalveluita & 0 \\
\hline \multicolumn{2}{|l|}{ Kampanjassa mukanaolo $(n=19)$} \\
\hline Ovat olleet mukana kampanjassa & 53 \\
\hline Eivät ole olleet mukana kampanjassa & 47 \\
\hline Ei osaa sanoa & 0 \\
\hline
\end{tabular}

viestintäkoulutukseen tai tuottaneet sisältöä kampanjan Instagram-tilille.

\section{Etsivät nuorisotyöntekijät}

Internetkysely lähetettiin 409 etsivälle nuorisotyöntekijälle. Sähköpostiosoitteet saatiin kampanjasivustolta. Kyselyyn vastasi 102 henkilöä (vastausprosentti: 25). Taustatietoina etsiviltä nuorisotyöntekijöiltä kysyttiin, millä alueella he työskentelevät ja minkä organisaation kautta he toimivat etsivässä työssä. Eniten vastaajia oli Pohjois- ja Itä-Suomen alueelta, mikä vastaa perusjoukon alueellista jakautumista. Valtaosa (84 \%) vastanneista työskenteli kunnalle. (Taulukko 3.)

\section{Kelan palveluneuvojat}

Kuntoutuksen palvelunumero on Kelan tarjoama puhelinpalvelu, jonka kautta henkilöasiakkaat ja kuntoutuksen sidosryhmät (esimerkiksi viranomaistahot) voivat hakea tietoa Kelan kuntoutusetuuksista. Palvelunumeroa mainostettiin nuorille kampanjasivustolla. Kysely lähetettiin sekä asiakkaiden että sidosryhmien palvelunumeroon vastaaville 105 palveluneuvojalle. Kyselyyn vastasi 49 henkilöä (vastausprosentti: 47). Palveluneuvojien taustatietoina kysyttiin, vastaavatko he asiakkaiden vai sidosryhmien puheluihin. Yli puolet (55 \%) kyselyyn vastanneista vastasi pelkästään asiakkailta tuleviin yhteydenottoihin. Runsas kolmannes (37 \%) vastasi sekä asiakkaiden että yhteistyökumppaneiden yhteydenottoihin.

Taulukko 3. Vastanneiden etsivien nuorisotyöntekijöiden taustatiedot, \% $(n=102)$.

\begin{tabular}{|c|c|}
\hline \multicolumn{2}{|l|}{ Suuralue $(n=99)$} \\
\hline Länsi-Suomi & 25 \\
\hline Helsinki-Uusimaa & 10 \\
\hline Etelä-Suomi & 22 \\
\hline Pohjois- ja Itä-Suomi & 42 \\
\hline \multicolumn{2}{|c|}{ Työskentelyorganisaatio ( $n=102$ ) } \\
\hline Kunta & 84 \\
\hline Yhdistys tai säätiö & 15 \\
\hline Jokin muu & 1 \\
\hline
\end{tabular}


Taulukko 4. Mikä Kunto? -kampanjan tunnettuus vastaajaryhmissä, \%.

\begin{tabular}{|lcccc|}
\hline & $\begin{array}{c}\text { Nuoret } \\
(\mathrm{n}=584)\end{array}$ & $\begin{array}{c}\text { Kuntoutuksen } \\
\text { palveluntuottajat } \\
(\mathrm{n}=19)\end{array}$ & $\begin{array}{c}\text { Etsivät } \\
\text { nuorisotyöntekijät } \\
(\mathrm{n}=102)\end{array}$ & $\begin{array}{c}\text { Kelan } \\
\text { palveluneuvojat } \\
(\mathrm{n}=49)\end{array}$ \\
\hline $\begin{array}{l}\text { On huomannut kampanjan } \\
\text { Ei ole huomannut kampanjaa }\end{array}$ & 3 & 79 & 51 & 90 \\
Ei osaa sanoa & 97 & 21 & 49 & 8 \\
\hline
\end{tabular}

\section{Tulokset}

\section{Mikä Kunto? -kampanjan tunnettuus}

Kampanjan tunnettuutta kartoitettiin kaikissa kohderyhmissä. Tulokset on esitetty taulukossa 4. Nuorilta kampanjan tunnettuutta tiedusteltiin kysymyksellä "Oletko huomannut Mikä Kunto? -kampanjan jossain, kuulostaako tutulta?". Puhelinhaastatteluun osallistuneista nuorista kolme prosenttia kertoi huomanneensa kampanjan. Kampanjan tunnettuudessa ei ollut alueellisia tai ikäryhmittäisiä eroja. Naiset olivat huomanneet kampanjan hieman miehiä paremmin: naisista kampanjan oli huomannut viisi prosenttia ja miehistä kaksi prosenttia.

Kampanjan huomanneille nuorille $(\mathrm{n}=20)$ esitettiin jatkokysymyksinä, missä he olivat nähneet kampanjan ja mitä heille oli jäänyt siitä mieleen. Noin viidennes (20\%) nuorista oli huomannut kampanjan Facebookissa. Huomattavasti harvempi muisti nähneensä kampanjamainontaa Youtubessa (5\%) tai Finnkinon elokuvateattereissa (5 \%). Puolet kertoi nähneensä kampanjamainontaa jossakin muualla, useimmiten internetissä tai oppilaitoksen ilmoitustaululla. Vastaajista 21 prosenttia ei osannut sanoa, missä he olivat mainontaa nähneet. Useimmille vastaajista kampanjasta oli jäänyt mieleen vain sen nimi ja positiivinen mielikuva. Osa muisti kampanjan liittyneen mielenterveyteen, johonkin tärkeään aiheeseen ja aktivoimiseen.

Tässäkin tutkimuksessa havaittiin, että tiedontarvetta kuntoutuspalveluista nuorilla kuitenkin on: enemmistö palveluntuottajista ja etsivistä nuorisotyöntekijöistä arvioi, että nuoret tuntevat huonosti Kelan järjestämiä kuntoutuspalveluita (taulukko 5). Palve- luntuottajista 11 prosenttia ja etsivistä nuorisotyöntekijöistä 18 prosenttia arvioi, etteivät nuoret tunne kuntoutuspalveluita lainkaan. Huolimatta siitä, että nuoret eivät juuri tunne kuntoutusetuutta, enemmistö etsivistä nuorisotyöntekijöistä arvioi, että 26 prosentilla tai suuremmalla osuudella heidän asiakkaistaan olisi tarvetta Kelan järjestämälle kuntoutukselle. Noin neljäsosa etsivistä nuorisotyöntekijöistä arvioi, että jopa yli puolella heidän kohtaamistaan nuorista olisi tarvetta kuntoutukselle. Toisaalta lähes vastaava osuus arvioi, että alle neljäsosa heidän asiakkaistaan hyötyisi kuntoutuksesta.

Mikä Kunto? -kampanjaan pyrittiin osallistamaan ne palveluntuottajat, jotka tuottavat ammatillisia ja mielenterveyskuntoutuspalveluita nuorille. Kyselyyn vastanneista palveluntuottajista 79 prosenttia ilmoitti kampanjan olevan tuttu ainakin osalle heidän henkilökunnastaan. Tavoitteestaan huolimatta tieto kampanjasta ei ollut saavuttanut kaikkia palveluntuottajia.

Etsivistä nuorisotyöntekijöistä hieman yli puolet (51 \%) oli huomannut Mikä Kunto? -kampanjan (taulukko 4). Kampanjan viestin

Taulukko 5. Miten hyvin nuoret tuntevat Kelan järjestämiä kuntoutuspalveluita palveluntuottajien ja etsivien nuorisotyöntekijöiden mukaan, \%.

\begin{tabular}{|lcc|}
\hline & $\begin{array}{c}\text { Palveluntuottajat } \\
(n=18)\end{array}$ & $\begin{array}{c}\text { Etsivät } \\
\text { nuorisotyöntekijät } \\
(n=102)\end{array}$ \\
Hyvin & 0 & 1 \\
Kohtalaisesti & 6 & 7 \\
Huonosti & 78 & 72 \\
Eivät ollenkaan & 11 & 18 \\
En osaa sanoa & 6 & 3 \\
\hline
\end{tabular}


Taulukko 6. Missä etsivät nuorisotyöntekijät ja Kelan palveluneuvojat olivat huomanneet Mikä Kunto? -kampanjan ja mitä heille oli jäänyt siitä mieleen, \%.

\begin{tabular}{|c|c|c|}
\hline & $\begin{array}{l}\text { Etsivät } \\
\text { nuorisotyöntekijät } \\
(\mathrm{n}=102)^{1}\end{array}$ & $\begin{array}{c}\text { Kelan } \\
\text { palveluneuvojat } \\
(n=49)^{1}\end{array}$ \\
\hline On nähnyt kampanjasta tiedotteen Kelan intranetissä/Kela.fi:ssä. & - & 59 \\
\hline On nähnyt kampanjan mainoksia internetissä. & 17 & 4 \\
\hline On nähnyt kampanjaan liittyneitä YouTube-videoita. & 6 & 16 \\
\hline On nähnyt kampanjan mainontaa elokuvissa tai televisiossa. & 4 & 2 \\
\hline On käynyt nuortenkuntoutus.kela.fi -kampanjasivustolla. & 21 & 20 \\
\hline Tietää, mikä kampanjan viesti ja tarkoitus on. & 15 & 18 \\
\hline Kampanjan nimi kuulostaa tutulta, muttei muista kampanjasta enempää. & 23 & 35 \\
\hline
\end{tabular}

ja tarkoituksen kertoi tietävänsä 15 prosenttia vastaajista ja viidesosa oli vieraillut kampanjasivustolla (taulukko 6). Toisaalta 23 prosenttia vastaajista ilmoitti, ettei heille ollut jäänyt kampanjasta mieleen muuta kuin sen nimi. Useimmiten etsivät nuorisotyöntekijät olivat huomanneet kampanjan internet-mainokset.

Kelan palveluneuvojista enemmistö (90 \%) muisti kuulleensa kampanjasta (taulukko 4). Kuitenkin vain 18 prosenttia heistä ilmoitti tuntevansa kampanjan viestin ja tarkoituksen, ja runsaalle kolmannekselle (35\%) kampanjasta oli jäänyt mieleen ainoastaan sen nimi (taulukko 6). Viidesosa palveluneuvojista oli käynyt kampanjasivustolla, ja suurin osa (59 \%) oli nähnyt kampanjasta tiedotteen Kelan intranetissä tai verkkosivuilla. Tulokset viittaavat siihen, ettei kampanjaviesti ole ollut riittävän selkeä, sillä se oli jäänyt epäselväksi suurelle osalle kampanjan huomanneista etsivistä nuorisotyöntekijöistä ja Kelan palveluneuvojista.

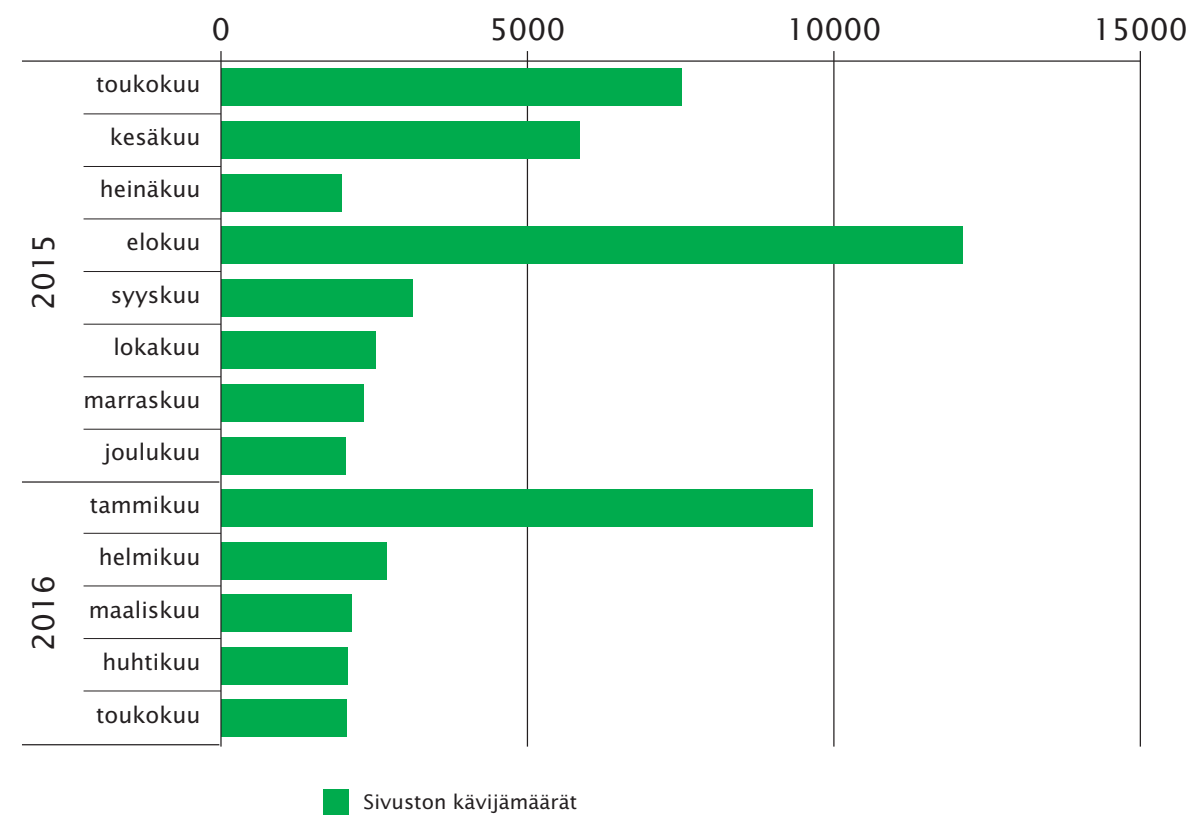

Kuvio 1. Kampanjasivuston kävijämäärät välillä toukokuu 2015-toukokuu 2016. Tiedot kerätty 6.6.2016. 
Taulukko 7. Kuinka suuri osa nuorten yhteydenotoista on vastaajaryhmien mukaan Mikä Kunto? -kampanjan vaikutusta, \%.

\begin{tabular}{|lccc|}
\hline & $\begin{array}{c}\text { Palveluntuottajat } \\
(n=19)\end{array}$ & $\begin{array}{c}\text { Etsivät } \\
\text { nuorisotyöntekijät } \\
(n=70)\end{array}$ & $\begin{array}{c}\text { Kelan } \\
\text { palveluneuvojat } \\
(n=49)\end{array}$ \\
Alle $10 \%$ & 68 & 37 & 43 \\
$10-20 \%$ & 5 & 4 & 12 \\
$21-30 \%$ & 0 & 0 & 4 \\
$31-50 \%$ & 0 & 0 & 0 \\
Yli 50\% & 0 & 0 & 0 \\
En osaa sanoa & 26 & 59 & 41 \\
\hline
\end{tabular}

Kaiken kaikkiaan kampanja näyttää tavoittaneen kattavasti kyselyyn vastanneet Kelan kuntoutuksen palveluneuvojat, kuntoutuksen palveluntuottajat ja etsivät nuorisotyöntekijät. Kampanjan markkinointi on nähtävissä myös kampanjasivuston kävijämäärissä (kuvio 1). Toukokuun ja elokuun 2015 sekä tammikuun 2016 kampanjalähdöt näkyvät sivuston kävijämäärien selvinä nousuina. Nuoret tavoitettiin kampanjalla kuitenkin huonosti, vaikka kampanjaa mainostettiin käyttäen heille tuttuja sähköisiä viestintäkanavia.

\section{Kampanjan vaikutukset}

Palveluntuottajia, etsiviä nuorisotyöntekijöitä ja Kelan palveluneuvojia pyydettiin arvioimaan, kuinka suuri osuus heille tulleista nuorten yhteydenotoista viimeisen vuoden aikana on Mikä Kunto? -kampanjan ansiota. Kaikki vastaajaryhmät arvioivat, että kampanja on vaikuttanut nuorten yhteydenottojen määrään vain vähän. Enemmistö (68 \%) palveluntuottajista, 37 prosenttia etsivistä nuorisotyöntekijöistä ja 43 prosenttia palveluneuvojista arvioi, että alle kymmenesosa nuorten yhteydenotoista on ollut Mikä Kunto? -kampanjan ansiota (taulukko 7). Pieni osa palveluntuottajista ja etsivistä nuorisotyöntekijöistä ja noin kymmenes palveluneuvojista arvioi yhteydenotoista 10-20 prosentin olleen kampanjan vaikutusta. Samoin pieni osa palveluneuvojista arvioi, että 21-30 prosenttia nuorten yhteydenotoista on kampanjan vaikutusta. Huomionarvoista on, että en osaa sanoa -vastausten osuus on suuri kaikissa vastaajaryhmissä. Tä- mä kertonee siitä, että kampanjan vaikutusten arviointi oli asiantuntijoille hankalaa, etenkin kun arviota pyydettiin tekemään yhteydenottotilanteiden jälkeen.

Etsiviltä nuorisotyöntekijöiltä tiedusteltiin lisäksi, kuinka monta nuorta he ovat ohjanneet viimeisen vuoden aikana Kelan kuntoutuspalveluihin Mikä Kunto? -kampanjan perusteella. Lähes puolet (45\%) etsivistä nuorisotyöntekijöistä arvioi ohjanneensa alle viisi nuorta Kelan järjestämiin kuntoutuspalveluihin. Pieni osa arvioi ohjanneensa 5-10 nuorta (4\%) tai 11-25 nuorta (3\%) kuntoutuspalveluihin kampanjan ansiosta. Tämänkin kysymyksen kohdalla huomattava osuus (49 \%) vastaajista ei osannut arvioida kampanjan vaikutuksia.

Kuntoutuksen palveluntuottajat ja etsivät nuorisotyöntekijät antoivat kampanjasta hyvin ristiriitaista palautetta, mikä täydentää aiemmin esitettyjä tuloksia. Osa palveluntuottajista kiitti kampanjan näkyvyyttä ja uudenlaista, nuoria puhuttelevaa viestintätyyliä. Samaan tapaan osa etsivistä nuorisotyöntekijöistä koki kampanjan erittäin myönteisenä viestintämuotona ja koki kampanjan parantaneen Kelan kuntoutuksen imagoa. Toisaalta palveluntuottajien kokemuksen mukaan kampanja ei näkynyt tarpeeksi eikä siitä tiedotettu heille riittävästi. Haasteena koettiin sosiaalisen median käyttö markkinoinnissa; palveluntuottajat kokivat, että sosiaalisen median käyttö ei ole heille yhtä arkipäiväistä ja luontevaa kuin nuorille.

Samoin valtaosa etsivistä nuorisotyöntekijöistä koki, ettei kampanja ollut tarpeeksi 
näkyvä eikä sitä markkinoitu heille riittävästi. Etsivät nuorisotyöntekijät kaipasivat kampanjasta huolimatta lisää tietoa kuntoutuksesta, Kelan yhdyshenkilöä, jolta voisi kysyä kuntoutusasioista, ja mahdollisuutta kasvokkaiseen neuvontaan kuntoutusasioissa Kelan työntekijän kanssa. Osa vastaajista ehdotti, että Ohjaamoissa voitaisiin tarjota neuvontaa kuntoutusasioissa. Kuntoutusvaihtoehdoista toivottiin lisää tietoa esimerkiksi koulutusten muodossa ja neuvontaa nuorten tukemiseen heidän yksilöllisissä elämäntilanteissaan. Vaikuttaa siltä, ettei kampanja tyydyttänyt nuorten kanssa työskentelevien tiedontarvetta kuntoutusasioista. Kuntoutuksesta toivotaan räätälöityä tietoa sekä neuvontaa silloin, kun tiedontarve on ajankohtainen.

\section{Pohdinta}

Mikä Kunto? -kampanjan tavoitteena oli lisätä nuorten ja nuorten kanssa työskentelevien tietoja Kelan järjestämistä kuntoutuspalveluista. Nuorista kolme prosenttia muisti kampanjan, mikä vastaa aiempien tutkimusten löydöksiä: seitsemän prosenttia kampanjan alkumittaukseen osallistuneista nuorista (OMD 2015) ja kaksi prosenttia Ohjaamoiden asiakkaista (Paavonen \&t Salminen 2016) oli huomannut kampanjan, kun kampanjan tunnettuutta kartoitettiin näyttämättä kampanjamainontaa. Enemmistö kuntoutuksen palveluntuottajista ja Kelan palveluneuvojista sekä hieman yli puolet etsivistä nuorisotyöntekijöistä oli huomannut kampanjan. Kaikki kampanjan huomanneet etsivät nuorisotyöntekijät ja palveluneuvojat eivät kuitenkaan tienneet, mistä kampanjassa oli kyse. Ammattilaisten mukaan kampanja oli hyvä ja uudenlainen tapa viestiä kuntoutusetuudesta, mutta se ei merkittävästi lisännyt nuorten kuntoutukseen hakeutumisen aikomuksia, joita tutkimuksessa mitattiin yhteydenottojen määränä. Tämä on luonnollista, jos vain kolme prosenttia nuorista huomasi kampanjan. Tutkimus osoittaa, ettei kampanja onnistunut tavoitteissaan: kampanja jäi huonosti kohderyhmien mieleen eikä havaittavasti lisännyt nuorten aikomusta hakeutua kuntoutukseen.
Kuten alkumittauksessa (OMD 2015) havaittiin, nuoret olisivat saattaneet muistaa kampanjan paremmin, jos heille olisi näytetty sen mainoskuvia. Kampanjan nimi ei ollut jäänyt heille kuitenkaan mieleen. On mahdollista, että internetmainosten kautta nuoret ovat jopa vierailleet kampanjasivustolla, mutta Mikä Kunto? -iskulausetta ei osattu yhdistää kampanjaan tai kuntoutuspalveluihin. Myös kampanjan kaikkia oheisvaikutuksia on vaikea arvioida. Se on esimerkiksi saattanut lisätä myönteistä suhtautumista Kelan järjestämiin kuntoutuspalveluihin, mikä tuli esille etsivien nuorisotyöntekijöiden vastauksissa.

Tutkimuksen vahvuutena on sen moninäkökulmainen aineisto. Tarkastelemalla samoja kysymyksiä erityyppisillä aineistolla ja menetelmillä saatiin toisia täydentäviä, tutkimuksen luotettavuutta vahvistavia aineistoja (Tuomi \&t Sarajärvi 2002, 141-142). Internetkyselyiden vastausprosentit olivat alhaisia, mikä asettaa rajoituksia tulosten yleistettävyydelle. Kattavaa katoanalyysiä ei voitu tehdä, koska perusjoukoista ei ollut käytettävissä tarpeeksi taustatietoja. Palveluntuottajien ja etsivien nuorisotyöntekijöiden kyselyiden vastauskato vaikuttaa kuitenkin jakautuneen alueellisesti suhteellisen tasaisesti ja noudattavan perusjoukkojen jakaumia. Matalien vastausprosenttien vuoksi saattaa olla, että vastaajiksi ovat valikoituneet esimerkiksi mielipiteiltään ääripäitä edustavat vastaajat. Internetkyselyissä vastausprosentti jää tyypillisesti kymmenisen prosenttia alhaisemmaksi kuin postikyselyissä (Shih \& Xitao 2008), joten tutkimuksen vastausprosentteja voidaan pitää internetkyselyille kohtuullisina. Poikkileikkausaineiston vuoksi tarkkaa tietoa nuorten kuntoutuspalveluiden tunnettuudesta kampanjaa edeltävältä ajalta ei ole. Aineistolla ei myöskään voida arvioida kampanjan tunnettuuden kehittymistä kampanjan aikana. Tutkimuksen toteuttamisessa noudatettiin tutkimuseettisen neuvottelukunnan (2009) laatimia eettisiä periaatteita. Internetkyselyyn osallistuneet ammattilaiset saivat tiedotteen tutkimuksesta, jossa kerrottiin, että osallistumalla tutkimukseen he antavan luvan tuottamansa aineiston käyttämiseen tutkimuksessa. Taloustutkimus Oy on sitoutunut 
noudattamaan alansa eettisiä ja tutkimuksen luotettavuutta koskevia ohjeistuksia. Vastaaminen oli nuorille vapaaehtoista ja nuoria koskeva tutkimusaineisto luovutettiin tutkijoille anonymisoituna.

Mikä Kunto? -kampanjassa pyrittiin ymmärrettävän, myönteisiä asenteita herättävän tiedon avulla tavoittamaan kuntoutuksesta mahdollisesti hyötyvät nuoret. Nämä keinot eivät osoittautuneet vaikuttaviksi. Kuntoutusetuuden osalta esimerkiksi etuudesta mahdollisesti hyötyvien henkilöiden kasaantuneet psyykkiset ja sosiaaliset rajoitteet (esim. Shemeikka ym. 2015) saattavat asettaa esteitä kuntoutukseen hakeutumiselle. Viestinnässä ja palvelujärjestelmässä tulisi panostaa asenteiden lisäksi toimintakykyyn liittyvien esteiden (esim. Ajzen 2005, 118) poistamiseen. Valinnanvapauden toteutumiselle kuntoutuspalveluissa saattaa olla haaste, jos mallissa luotetaan liiaksi oletukseen harkittuja valintoja tekevästä toimijasta. Terveyteen liittyvät valinnat eivät aina perustu harkintaan, kuten valintoja selittävät teoriat (esim. Ajzen 2005, 117-127) ennustavat (esim. Fotaki ym. 2008).

Osalla elämänkolhuista kärsivistä nuorista toimijuus on vasta rakentumassa, eivätkä he koe olevansa valmiita tai kykeneviä tekemään itsenäisesti elämäänsä koskevia isoja päätöksiä (Juvonen 2015). Vasta kehittymässä olevat elämäntaidot ja puutteellinen elämänkokemus saivat nuoret varovaisiksi käyttämään valinnanvapauttaan vammaisille suunnatuissa terveys- ja hoivapalveluissa englantilaisessa valinnanvapausjärjestelmässä (Mitchell ym. 2016). Luotettavan aikuisen, kuten vanhempien, tuki nähtiin tarpeellisena valintatilanteessa. Saattaa olla, että valintoja ja elämänmuutoksen tekemistä tukeva sosiaalinen toimintakyky ja elämänhallinta rakentuvatkin vasta kuntoutuksen avulla (esim. Savukoski \&t Kauramäki 2012, 125).

Kohderyhmän tavoittamiseksi tarkoituksenmukaisempaa saattaisi olla lähestyä henkilökohtaisesti kuntoutusetuudesta mahdollisesti hyötyviä nuoria. Aiemmissa tutkimuksissa henkilökohtaisen neuvonnan tarjoaminen on lisännyt etuuden käyttöastetta (Bettinger ym. 2012) tai se on saanut potentiaaliset käyttä- jät harkitsemaan etuuden käyttöä (Eloranta 2008). Korkeamäen (2015) mukaan nuorten kanssa työskentelevien ammattilaisten rooli on keskeinen, jotta nuoret tietävät kuntoutusmahdollisuuksista ja ohjautuvat käyttämään niitä. Nuorten on todettu kaipaavan palvelujärjestelmässä henkilökohtaista kohtaamista (esim. Aaltonen ym. 2015, 130; Paavonen \&t Salminen 2016), matalaa kynnystä palveluihin ja luottamusta heitä auttavaan ammattilaiseen (Aaltonen ym. 2015, 130). Valinnanvapauden kontekstissa digitalisaatiota ja sen tuomia tiedon jakamisen mahdollisuuksia on esitetty vastaukseksi palveluntuottajia koskevan vertailutiedon tasavertaiseen saatavuuteen eri väestöryhmien kesken. Pelkkien sähköisten asiointimahdollisuuksien lisääminen saattaa nuorten kohdalla olla askel väärään suuntaan (esim. Aaltonen ym. 2015, 132).

Suomalaisessa valinnanvapausmallissa pyritään järjestämään tukea niille asiakasryhmille, joilla on rajalliset mahdollisuudet käyttää valintaoikeuttaan (Sosiaali- ja terveysministeriö \&t valtiovarainministeriö 2016). Valinnanvapauden aito toteutuminen edellyttää myös asiakkaiden tietoisuutta käytettävissä olevista palveluista. Tämän tutkimuksen mukaan myönteisiä asenteita herättävällä viestintäkampanjalla ei tavoitettu nuoria, joille kuntoutuksesta voisi olla apua. Nuorten hakeutumista kuntoutuspalveluihin voitaisiin todennäköisesti edistää paremmin panostamalla palveluntarpeen arvioimiseen ja tarvittavien palveluiden tunnistamiseen. Tieto kuntoutusmahdollisuuksista tulisi sisällyttää osaksi palvelujärjestelmää. Esimerkiksi Ohjaamot, nuorten matalan kynnyksen palvelupisteet, voivat tulevaisuudessa olla hyvä kanava tarjota tukea kuntoutukseen hakeutumisessa. Jos tarjolla ei ole riittävää tukea palveluista saatavilla olevan tiedon hyödyntämiseen, valinnanmahdollisuudet saattavat syrjäyttää nuoren palvelujärjestelmästä voimaannuttamisen ja itsemääräämisoikeuden vahvistamisen sijaan. Tällöin palveluntuottajan valinnasta tulee toissijainen kysymys. 
Tulosten merkitys: Kuntoutusviestintää suunniteltaessa tulee hyödyntää viestintäkeinoihin ja sen kohderyhmään liittyvää tutkimus- ja teoriatietoa. Tiedon tarjoamisen lisäksi nuorten hakeutumista kuntoutukseen tulisi tukea henkilökohtaisella neuvonnalla. Valinnanvapauden toteutumiseksi kuntoutuspalveluissa erityistä huomiota tulisi kiinnittää tiedon tarjoamisen keinoihin.

\section{Tiivistelmä}

Asiakkaan valinnanvapauden lisääminen on osa suomalaisen sosiaali- ja terveyspalvelujärjestelmän uudistamista. Valinnanvapauden toteutumisen edellytyksenä on, että asiakkailla on tietoa valittavina olevista palveluista ja että he kykenevät käyttämään tietoa valintojen tekemiseen. Nuoret tuntevat kuntoutuspalvelut huonosti, vaikka heillä olisi tarvetta niille. Tässä tutkimuksessa tarkastellaan Kelan vuosina 2015-2016 toteuttamaa nuorten kuntoutuspalveluiden viestintäkampanjaa (Mikä Kunto?), jonka tarkoituksena oli lisätä nuorten ja nuorten kanssa työskentelevien tietämystä Kelan järjestämistä kuntoutuspalveluista. Tulosten avulla pohditaan, millainen on tiedon merkitys valinnanvapauden edellytyksenä nuorten kuntoutuspalveluissa.

Tutkimuksen aineisto kerättiiin keväällä 2016 puhelinhaastatteluna ja internetkyselyin. Tutkimuksen informantteina ovat viestintäkampanjan kohderyhmänä olleet 16-30-vuotiaat nuoret ( $\mathrm{n}=584$ ), kuntoutuksen palveluntuottajat ( $n=19$ ), etsivät nuorisotyöntekijät $(n=102)$ ja Kelan palveluneuvojat, jotka vastaavat kuntoutuksen palvelunumeroon $(\mathrm{n}=49)$. Informanteilta kysyttiin, ovatko he huomanneet kampanjan ja onko kampanja vaikuttanut nuorten yhteydenottojen määrään ammattilaisiin kuntoutusasioissa. Lisäksi tarkasteltiin kampanjasivuston kävijämääriä.
Enemmistö kuntoutuksen palveluntuottajista ja Kelan palveluneuvojista oli huomannut kampanjan. Sen sijaan puolet etsivistä nuorisotyöntekijöistä ja kolme prosenttia nuorista muisti kampanjan. Ammattilaisten mukaan nuoret olivat olleet vain vähän yhteydessä heihin kampanjan vaikutuksesta. Kampanjasivuston markkinointi näkyi sivuston kävijämäärissä.

Viestintäkampanjan sijaan nuorten ohjautumista kuntoutuspalveluihin saattaisi olla parempi edistää tarjoamalla henkilökohtaista neuvontaa kuntoutuksesta mahdollisesti hyötyville nuorille. Jos tarjolla ei ole tukea palveluista saatavilla olevan tiedon hyödyntämiseen, nuoret saattavat jäädä palveluiden ulkopuolelle, jolloin palveluntuottajan valinnasta tulee toissijainen kysymys.

Avainsanat: valinnanvapaus, tieto, kuntoutus, nuorten palvelut

\section{Abstract}

Information as a precondition for patient choice. How a marketing campaign succeeded to add knowledge on youth rehabilitation services?

Authors:

Anna-Marie Paavonen, M.Soc.Sci, Research assistant, Research at Kela Jenna Mäkinen, M.Soc.Sci, Research assistant, Research at Kela Anna-Liisa Salminen, PhD, Docent, Head of Research Team, Research at Kela

One precondition for patient choice in the public health care system is that comparative information on service providers is available. If patient choice is to improve the quality of health care patients should be able to use the available information appropriately. Finnish studies have shown that the youth is poorly informed about the vocational and mental 
health rehabilitation services. This study examines the effects of a marketing campaign (Mikä Kunto?) which aimed to raise youth awareness of rehabilitation services. The campaign was carried out by the Social Insurance Institution of Finland (Kela) in 2015-2016. The results are utilized to discuss the role of information as a precondition for patient choice in the youth rehabilitation services.

The data was collected using a telephone interview and online questionnaires. The informants were young people aged $16-30$ years $(n=584)$, rehabilitation providers $(\mathrm{n}=19)$, youth workers in outreach youth work $(n=102)$ and Kela employees responsible for the rehabilitation phone services $(n=49)$. Informants' awareness of the campaign was measured and the number of contacts by the youth with the latter informants in matters of rehabilitation. The analysis is complemented with the information on the number of visitors to the campaign website.

A majority of the rehabilitation providers and Kela employees had noticed the campaign. In contrast, three percent of the youth and half of the youth workers in outreach youth work had noted it. The campaign affected only little the number of contacts by youth in matters of rehabilitation. Marketing of the campaign was shown in the number of visitors to the campaign website.

Instead of a marketing campaign it could be more efficient to increase rehabilitation take-up by providing personal counselling to the youth in detecting rehabilitation need and in case management. If support for the use of available information is not offered the youth may not get the services they need and the possibility to choose the service provider becomes an irrelevant question.

Key words: patient choice, information, rehabilitation, youth services

\section{Anna-Marie Paavonen, VTM, tutkimusassistentti,} Kelan tutkimus

\section{Jenna Mäkinen, VTM, tutkimusassistentti, Kelan tutkimus}

Anna-Liisa Salminen, PhD, dosentti, tutkimustiimin päällikkö, Kelan tutkimus

\section{Lähteet}

Aaltonen S, Berg P, Ikäheimo S (2015) Nuoret luukulla. Kolme näkökulmaa syrjäytymiseen ja nuorten asemaan palvelujärjestelmässä. Nuorisotutkimusverkosto/Nuorisotutkimusseura, Verkkojulkaisuja 84, Helsinki.

Ajzen I (2005) Attitudes, Personality and Behavior. Open University Press, Maidenhead.

Bettinger E, Bridget T, Oreopoulos P, Sanbonmatsu L (2012) The role of application assistance and information in college decisions: results from the HAR block FAFSA experiment. The Quarterly Journal of Economics 127, 7, 1205-1242.

Currie J (2006) The Take-up of Social Benefits. Teoksessa A Auerbach, D Card, J Quigley (toim.) Public Policy and the Income Distribution. Russell Sage Foundation, New York.

Damman 0, Hendriks M, Rademakers J, Delnoij D, Groenewegen P (2009) How do health care consumers process and evaluate comparative health care information? A qualitative study using cognitive interviews. BMC Public Health 2009, 9, 423.

Eloranta M (2008) Sosiaali- ja terveysministeriön perhevapaakampanja 2007-2008. Loppuraportti. Sosiaali- ja terveysministeriön selvityksiä 22, Helsinki.

Eskola J, Suoranta J (2000) Johdatus laadulliseen tutkimukseen. Vastapaino, Jyväskylä.

Fotaki M, Roland M, Boyd A, McDonald R, Scheaff R, Smith L (2008) What benefits will choice bring to patients? Literature review and assessment of implications. Journal of Health Services Research and Policy 13, 3, 178-184.

Gustavsson-Lilius M, Lehtoranta P, Mentula T, Ketola M, Poutiainen E (2015) Mielenterveyden ja oppimisen ongelmat nuorten syrjäytymisen taustalla. Kuntoutus 37, 1, 22-27.

Jonsson PM, Virtanen M (2013) Miten valinnanvapaus voidaan toteuttaa terveydenhuollossa. Suomen lääkärilehti 68, 1990-1993.

Junnila M, Sinervo T, Aalto AM, Jonsson PM, Hietapakka L, Keskimäki I, Pekurinen M, Seppälä TT, Tynkkynen LK, Whellams A (2016) Valinnanvapaus sosiaali- ja terveydenhuollossa - kriittiset as- 
keleet toteuttamisessa. Terveyden ja hyvinvoinnin laitos, Päätösten tueksi 2, Helsinki.

Juvonen T (2015) Sosiaalisesti kontrolloitu, hauraasti autonominen: nuorten toimijuuden rakentuminen etsivässä työssä. Nuorisotutkimusseura/Nuorisotutkimusverkosto, julkaisunumero 165, Helsinki.

Kahnemann D, Tversky A (1979) Prospect Theory: An Analysis of Decision under Risk. Econometrica 47, 2, 263-291.

Kelan tilastollinen vuosikirja (2015) Kansaneläkelaitos, Helsinki.

Korkeamäki J (2015) Nuorisotakuu haastaa kuntoutuksen. Kuntoutus 37, 1, 28-34.

Martelin T, Koskinen S, Kestilä L, Aromaa A (2005) Terveyden ja toimintakyvyn vaihtelu asuinalueen, koulutuksen ja kotitaloustyypin mukaan. Teoksessa S Koskinen, L Kestilä, T Martelin, A Aromaa (toim.) Nuorten aikuisten terveys. Terveys 2000 -tutkimuksen perustulokset 18-29-vuotiaiden terveydestä ja siihen liittyvistä tekijöistä. Kansanterveyslaitos, Kansanterveyslaitoksen julkaisuja B 7, Helsinki.

Mitchell W, Beresford B, Brooks J, Moran N, Glendinning C (2016) Taking on choice and control in personal care and support: the experiences of physically disabled young adults. Journal of Social Work 0, 0, 1-21.

OMD (2015) Kela-kampanjamittaus. Nuorten kuntoutuspalvelut. OMD, Helsinki.

Paavonen AM, Salminen AL (2016) Kelan ja Ohjaamoiden yhteistyö. Selvitys Kelan roolista nuorten matalan kynnyksen palveluissa. Kela, Työpapereita 103 , Helsinki.

Petty RE, Cacioppo JT (1986) Communication and persuasion: Central and peripheral routes to attitude change. Springer-Verlag, New York.

Savukoski M, Kauramäki P (2012/2004) Nuoren sosiaalinen tukeminen omalle ammatilliselle uralle. Teoksessa V Karjalainen, I Vilkkumaa (toim.) Kuntoutus kanssamme - Ihmisen toimijuuden tukeminen. Sosiaali- ja terveysalan tutkimus- ja kehittämiskeskus, Helsinki.

Shemeikka R, Rinne H, Sainio P, Karvonen S, Saares A, Murto J, Koskinen S, Kaikkonen R (2015) Nuorten aikuisten toimintakyvyn väestöryhmittäiset erot. Kuntoutus 37, 1, 6-21.

Shih TH, Xitao F (2008) Comparing response rates from web and mail surveys: A meta-analysis. Field methods 20, 249-271.

Sosiaali- ja terveysministeriö, valtiovarainministeriö (2016) Valinnanvapauden toteuttamisen ja monikanavaisen rahoituksen yksinkertaistamisen jatkovalmistelu. Sosiaali- ja terveysministeriö, val- tiovarainministeriö. http://alueuudistus.fi/docum ents/1477425/2969576/12.+Valinnanvapaus-+ja +monikanavarahoituslinjaus+2016-06-27 (luettu 4.7.2016).

SOSTE (2016) Kuntoutusverkoston asiantuntijat: Valinnanvapaus on kuntoutujan mahdollisuus. Suomen sosiaali ja terveys ry. http://www.soste.fi/ ajankohtaista/kuntoutusverkoston-asiantuntijatvalinnanvapaus-on-kuntoutujan-mahdollisuus. html (luettu 27.6.2016).

Terveydenhuoltolaki 2010/1326. http://www.finlex. fi/fi/laki/ajantasa/2010/20101326\#L6P47. (luettu 11.8.2016).

Tilastokeskus (2015) Kunnat ja kuntapohjaiset aluejaot 2015. Tilastokeskus, Helsinki.

Tuomi J, Sarajärvi A (2002) Laadullinen tutkimus ja sisällönanalyysi. Tammi, Helsinki.

Tuusa M, Pitkänen S, Shemeikka R, Korkeamäki J, Harju H, Saares A, Pulliainen M, Kettunen A, Piirainen K (2014) Yhdessä tekeminen tuottaa tuloksia nuorisotakuun tutkimuksellisen tuen loppuraportti. Työ- ja elinkeinoministeriö, Helsinki.

Tutkimuseettinen neuvottelukunta (2009) Humanistisen, yhteiskuntatieteellisen ja käyttäytymistieteellisen tutkimuksen eettiset periaatteet ja ehdotus eettisen ennakkoarvioinnin järjestämiseksi. Tutkimuseettinen neuvottelukunta, Helsinki.

Valtioneuvoston kanslia (2015) Hallitus päätti soteuudistuksen jatkosta ja itsehallintoalueista. Valtioneuvoston kanslia. http://valtioneuvosto.fi/artikkeli/-/asset_publisher/hallitus-paatti-sote-uudistuksen-jatkosta-ja-itsehallintoalueista?_101_ INSTANCE_3wyslLo1Z0ni_groupId=10616 (luettu 29.6.2016)

Victoor A, Delnoij DMJ, Friele RD, Rademakers JJDJM (2012) Determinants of patient choice of healthcare providers: A scoping review. BMC Health Services Research 12, 1, 272-287. 